\title{
ANALISIS BIAYA PENGOBATAN PASIEN PENYAKIT JANTUNG KORONER DENGAN PENYAKIT PENYERTA DI RUMAH SAKIT
}

\author{
Ikhwan Dwi Wahyu Nugroho*1, Lilian Pingky Sukmawati ${ }^{2}$, Tri Fitri Yana Utami ${ }^{3}$ \\ Program Studi Sl Farmasi, STIKES Al-Irsyad Al-Islamiyyah, Cilacap, Jawa Tengah, Indonesia \\ e-mail: ${ }^{* 1}$ ikhwandwiwahyunugroho@yahoo.co.id, ${ }^{2}$ lilianpingky@gmail.com, \\ ${ }^{3}$ trifitriyana@mail.ugm.ac.id
}

\begin{abstract}
ABSTRAK
Adanya keterkaitan Penyakit Jantung Koroner(PJK) dengan faktor resiko dan penyakit penyerta menyebabkan kompleksnya terapi yang diberikan sehingga membutuhkan biaya yang besar. Penelitian ini bertujuan untuk mengetahui profil penggunaan obat, profil biaya pengobatan dan hubungan biaya pengobatan dengan jumlah penggunaan obat kardiovaskular pada pasien PJK di instalasi rawat jalan RS X periode bulan Januari - Desember 2019. Penelitian ini merupakan penelitian dengan metode cross sectional dengan pengambilan data secara retrospektif terhadap 55 data rekam medik pasien PJK rawat jalan yang memenuhi kriteria inklusi dan esklusi. Hasil penelitian berdasarkan karakteristik pasien PJK menunjukkan jumlah pasien laki-laki lebih banyak dibandingkan perempuan yaitu sebesar 51 pasien (92,7\%) dan jumlah pasien terbanyak pada kelompok usia 56 - 65 tahun sebesar 35 pasien (63,6\%). Penyakit hipertensi merupakan penyakit penyerta terbanyak yang ditemukan pada 28 pasien $(51,0 \%)$ dan $6-10$ jenis obat diresepkan pada 24 pasien (43,6\%). Total biaya terapi penggunaan obat kardiovaskular pada seluruh pasien penyakit jantung koroner dengan penyakit penyerta selama menjalani rawat jalan di RS X sebesar Rp 35.367.890 dengan penggunaan obat paling banyak pengeluarannya yaitu clopidogrel sebesar $R p$ 8.567.307 dan obat paling sedikit yang digunakan adalah captopril sebesar Rp 224. Adanya hubungan yang kuat antara biaya pengobatan yang dikeluarkan dengan jumlah penggunaan obat kardiovaskular.
\end{abstract}

Kata kunci: analisis biaya obat, penggunaan obat, penyakit jantung koroner.

\begin{abstract}
The correlation between coronary heart disease (CHD) with risk factors and comorbidities causes the complexity of therapy given, so it is costly. This study aims to determine the profile of drug use, the profile of medical costs and the relationship between treatment costs and the amount of use of cardiovascular drugs in CHD patients at the outpatient installation of RS X for the period January December 2019. The results of the study based on characteristics of CHD patients showed the number of male patients was more than that of women, namely 51 patients (92.7\%) and the highest number of patients was in the 56-65 years age group of 35 patients (63.6\%). Hypertension was the most comorbid disease found in 28 patients (51.0\%) and 6-10 types of drugs were prescribed in 24 patients (43.6\%). The total cost of therapy for the use of cardiovascular drugs for all coronary heart disease patients with comorbidities while undergoing outpatient care at X Hospital was IDR 35,367,890 with the most expenditure of the drug, clopidogrel, was IDR 8,567,307 and the least drug used was captopril of IDR 224. There is a strong relationship between medical expenses incurred and amount of use of cardiovascular drugs.
\end{abstract}

Keyword: Coronary Heart Disease (CHD), Medication cost analysis, Medication use

\section{PENDAHULUAN}

Pada data Kemenkes 2017 menurut World Health Organization (WHO) tahun 2016 dari 56,9 juta kematian di seluruh dunia, lebih dari setengah (54\%) disebabkan oleh 10 penyebab utama [1]. Secara nasional sepuluh penyebab kematian tertinggi adalah penyakit pembuluh darah otak (21\%), penyakit jantung iskhemik (12,9\%), diabetes mellitus $(6,7 \%)$, TBC $(5,7 \%)$, hipertensi dengan komplikasinya (5,3\%), penyakit saluran napas bawah kronik $(4,9 \%)$, 
penyakit hati $(2,7 \%)$, kecelakaan transportasi $(2,6 \%)$, pneumonia $(2,1 \%)$ dan diare $(1,9 \%)$ [2]. pembunuh terbesar di dunia salah satunya adalah penyakit jantung iskemik dan stroke, dan bertanggung jawab atas 15,2 juta kematian gabungan pada 2016 [1]. Survei Sample Regristration System (SRS) di Indonesia pada tahun 2014 menunjukkan, Penyakit jantung koroner (PJK) dengan penyakit penyerta menjadi penyebab kematian tertinggi pada semua umur setelah stroke, yaitu sebesar 12,9\% [3].

Usaha peningkatan kualitas kesehatan masyarakat oleh pemerintah diwujudkan dalam berbagai program kesehatan, misalnya memberikan kemudahan akses pelayanan publik [4]. Dalam rangka mewujudkan jaminan kesehatan yang berkualitas dan berkesinambungan dibentuklah Badan Penyelenggara Jaminan Sosial (BPJS) sebagai bentuk implementasi dari diterapkannya sistem Jaminan Kesehatan Nasional (JKN) sejak 2014 [5].

Menurut penelitian yang dilakukan AHA (2016), antara tahun fiskal 2015 terjadi peningkatan biaya rata-rata belanja obat sebesar $23,4 \%$ pertahun, sementara berdasarkan penerimaan sebesar 38,7\%. Sebanyak lebih dari 90\% rumah sakit di Amerika melaporkan bahwa pembiayaan obat pada pasien rawat inap mengalami kenaikan sehingga memberi dampak antara sedang hingga berat pada kemampuan mereka dalam mengelola keseluruhan pembiayaan pasien [6].

Pada pembiayaan satuan dan pemulihan biaya (cost recovery rate) layanan pasien Acute Coronary Syndrome dengan rawat inap di rumah sakit X tahun 2015 dapat diperoleh hasil analisis Cost Recovery Rate untuk pasien umum adalah 22,798 \% dan pasien BPJS adalah 71,38 $\%$ [7]. Pada analisis biaya akibat sakit serta kualitas hidup pasien Diabetes Mellitus tipe 2 dengan Penyakit Jantungdapat menunjukkan bahwa rata-rata biaya pasien akibat sakit Diabetes Mellitus tipe 2 dengan Penyakit Jantung selama setahun adalah Rp 6.081 .572 dan proporsi terbesar adalah biaya obat $(37,05 \%)[8]$.

Tujuan dari penelitian ini yaitu untuk mengetahui profil penggunaan obat, profil biaya pengobatan dan ada tidaknya hubungan antara biaya pengobatan dengan penggunaan obat kardiovaskular pada pasien penyakit jantung koroner dengan penyerta yang melakukan pengobatan rawat jalan di Rumah Sakit X Kabupaten Cilacap tahun 2019.

\section{METODE PENELITIAN}

Kriteria inklusi pada penelitian ini adalah pasien rawat jalan PJK dengan penyakit penyerta yang menggunakan pengobatan obat golongan kardiovaskular. Kriteria eksklusi pada penelitian ini adalah pasien dengan diagnosa tunggal PJK yaitu tanpa penyakit penyerta dan menjalani pengobatan yang tidak rutin. Selanjutnya data dianalisis secara deskriptif menggunakan program Microsoft Office Excel dan SPSS statistics untuk mengetahui demografi pasien (umur, jenis kelamin, penyakit penyerta, jenis obat golongan kardiovaskular dan biaya pengobatan obat golongan kardiovaskular).

\subsection{Alat dan Bahan}

Instrumen penelitian atau alat yang digunakan yaitu rekammedik, resep dan data biaya obat kardiovaskular.

\subsection{JalannyaPenelitian}

Pembuatan surat penelitian ke bagian PJ S1 Farmasi untuk di kirim ke Rumah Sakit X Kabupaten Cilacap, Permintaan ijin penelitian kepada pihak Rumah Sakit X Kabupaten Cilacap pada bagian diklat, probang dan direktur, tepatnya pada bagian rekam medik dan instalasi farmasi rumah sakit dengan menunjukkan surat ijin penelitian yang telah disetujui oleh Direktur Rumah Sakit X Kabupaten Cilacap,pembuatan surat perizinan ke Badan Kesatuan Bangsa dan Politik, Badan Perencanaan Pembangunan Penelitian dan Pengembangan Daerah Kabupaten Cilacap, Pembuatan EthicalClearance ke Komisi Etik Penelitian Kesehatan dan Fakultas Kedokteran dan Ilmu-ilmu Kesehatan Universitas Jendral Soedirman, Dibuat lembar pengumpulan data berdasarkan rekam medik dan instalasi farmasi rumah sakit di Rumah Sakit X Kabupaten Cilacap, dilakukan penapisan terhadap calon sampel yang memenuhi kriteria inklusi dan eksklusi yang telah ditetapkan, Setelah 
pengumpulan data selesai, selanjutnya dilakukan pengolahan data dengan ms. Excel dan SPSS pada proses editing,codingdanentry data, dilakukan analisis data dengan melakukan statistika deskriptif, uji normalitas dan analisis statistika.

\subsection{Analisis Data}

Metodeanalisis data yang digunakan yaitu uji uji normalitas menggunakan Kolmogorovsmirnov test dan uji korelasi menggunakan uji Pearson antara jumlah penggunaan jenis obat golongan kardiovaskular dengan biaya pengobatan obat golongan kardiovaskular.

\section{HASIL DAN PEMBAHASAN}

Hasil penelitian secara retrospektif pada pasien rawat jalan penyakit jantung koroner dengan penyakit penyerta yang melakukan pengobatan rawat jalan di Rumah Sakit X Kabupaten Cilacap pada bulan Januari - Desember 2019 diperoleh populasi sebanyak 98 pasien. Populasi merupakan pasien rawat jalan penyakit jantung koroner dengan penyakit penyerta yang menjalani pengobatan di Rumah Sakit X. Sebanyak 43 pasien masuk ke kriteria eksklusi dan pasien yang memenuhi kriteria inklusi dan eksklusi sebanyak 55 pasien, yaitu pasien yang memiliki data rekam medik lengkap dengan diagnosa PJK dengan penyakit penyerta dan menerima terapi golongan kardiovaskular.

\subsection{Karakteristik pasien}

Karakteristik pasien dengan penyakit jantung koroner yang menjalani pengobatan rawat jalan penyakit jantung koroner dengan penyakit penyerta di Rumah Sakit X Kabupaten Cilacap pada bulan Januari - Desember 2019 berdasarkan jenis kelamin dan usia dapat dilihat pada tabel I.

Tabel I. Karakteristik pasien rawat jalan penyakit jantung koroner dengan penyakit penyerta di Rumah Sakit X pada bulan Januari - Desember 2019

\begin{tabular}{|c|c|c|c|c|}
\hline $\begin{array}{c}\text { Karakteristik } \\
\text { pasien }\end{array}$ & Variasi Kelompok & Jumlah & $\begin{array}{c}\text { Prosentas } \\
\text { e }(\%)\end{array}$ & $\begin{array}{l}\text { Total } \\
\text { Pasien }\end{array}$ \\
\hline \multirow{2}{*}{$\begin{array}{c}\text { Berdasarkan jenis } \\
\text { kelamin }\end{array}$} & Laki-laki & 51 & 92,7 & \multirow{2}{*}{55} \\
\hline & Perempuan & 4 & 7,3 & \\
\hline \multirow{5}{*}{$\begin{array}{r}\text { Berdasarkan usia } \\
\text { (Depkes RI 2009) }\end{array}$} & (masa dewasa awal) $26-35$ & 0 & 0 & \multirow{5}{*}{55} \\
\hline & (masa dewasa akhir) $36-45$ & 0 & 0 & \\
\hline & (masa lansia awal) $46-55$ & 6 & 10,9 & \\
\hline & (masa lansia akhir) $56-65$ & 35 & 63,6 & \\
\hline & (masa manula) & 14 & 25,5 & \\
\hline
\end{tabular}

Sumber: Data mentah yang diolah, 2019

Berdasarkan tabel I, didapatkan bahwa penderita penyakit jantung koroner sering terjadi pada pasien dengan jenis kelamin laki-laki sebanyak 51 pasien $(92,7 \%)$ dibandingkan pasien dengan jenis kelamin perempuan sebanyak 4 pasien $(7,3 \%)$. Hasil penelitian tersebut sesuai dengan penelitian Martha (2016) [9] yang mengatakan bahwa pasien dengan jenis kelamin laki-laki sebanyak 29 pasien $(64,45 \%)$ lebih banyak terjadi dari pada jenis kelamin perempuan sebanyak $16(35,55 \%)$. Perbedaan tersebut dikarenakan adanya proses ateroskelosis terjadi dalam waktu yang lama sejak usia 15 tahun, pada laki-laki usia 40 tahun keatas kenaikan kadar kolesterol dalam darah mempunyai resiko yang tinggi khususnya LDL untuk pembentukan penyakit jantung koroner, sedangkan perempuan mempunyai perlindungan alami dari resiko penyakit jantung koroner yaitu hormon estrogen yang bisa sangat membantu dalam pengendalian kolesterol. Selain itu juga pola hidup yang kurang sehat seperti merokok juga menambah faktor resiko dari jenis kelamin laki-laki [9].

Perbedaan jenis kelamin dapat mempengaruhi struktur pembuluh darah. Perempuan memiliki tipe pembuluh darah yang lebih kecil dan perbedaan diameter saluran pembuluh darah dibandingkan dengan laki-laki. Hal tersebut juga dipengaruhi pada tingginya tekanan darah [10].

Bertambahnya usia memungkinkan rentan terkena penyakit kardiovaskular. Kejadian PJK meningkat lima kali lipat pada usia 40-60 tahun. Secara fisiologis pertambahan usia akan menyebabkan terjadinya perubahan secara fisiologis pada jantung, diantaranya adalah 
otot jantung akan menjadi lebih kaku, dinding jantung mengalami penebalan dan struktur pembuluh darah mengalami perubahan yang menyebabkan pembuluh darah kurang elastis dan meningkatkan tekanan sistolik [11].

Tabel II. Distribusi Penyakit Penyerta Pada Pasien Jantung Koroner

\begin{tabular}{clcc}
\hline No & \multicolumn{1}{c}{ Penyakit penyerta } & Jumlah Pasien & Prosentase (\%) \\
\hline 1 & Hipertensi & 28 & 51,0 \\
2 & Diabetes mellitus & 10 & 18,1 \\
3 & Hiperkolesterolemia & 4 & 7,3 \\
4 & Stroke hemoragik & 3 & 5,5 \\
5 & Diagnosa penyerta lain & 10 & 18,1 \\
\hline \multicolumn{2}{r}{ TOTAL } & 55 & 100 \\
\hline
\end{tabular}

Berdasarkan tabel II, penyakit penyerta terbanyak yang menyertai penyakit jantung koroner adalah hipertensi sebanyak 28 pasien $(51,0 \%)$, diabetes melitus sebanyak 10 pasien $(18,1 \%)$, hiperkolesterolemia sebanyak 4 pasien $(7,3 \%)$, stroke hemoragiksebanyak 3 pasien $(5,5 \%)$, dan dengan penyakit penyerta lain sebanyak 10 pasien $(18,1 \%)$ dari jumlah sampel total 55 orang. Hasil dari penelitian tersebut sejalan penelitian yang dilakukan Krishna et. al (2013) dimana kematian akibat penyakit jantung koroner yang disertai dengan hipertensi meningkat sekitar 9,4\% dari tahun 2008, dan selain itu penelitian Townsend (2012) menyatakan $50 \%$ penyakit jantung koroner dinegara berkembang yang terjadi disebabkan oleh hipertensi [12].

\subsection{Profil Penggunaan Obat}

\subsubsection{Profil Penggunaan Obat Injeksi}

Berdasarkan profil penggunaan obat injeksi, pasien rawat jalan yang menderita PJK dapat dilihat ditabel dibawah ini.

Tabel III. Presentase Distribusi Jumlah Pasien Berdasarkan Profil Penggunaan Obat Injeksi

\begin{tabular}{clcc}
\hline No. & \multicolumn{1}{c}{ Nama Obat } & Frekuensi & Persentase \% \\
\hline 1 & Sansulin Log-G 100 IU/ml Injeksi & 49 & 89,1 \\
2 & Sansulin Pen & 1 & 1,8 \\
3 & Novorapid Flexpen_Al01 & 2 & 3,6 \\
4 & Mecobalamin 500 mcg Injeksi Nulab & 9 & 16,4 \\
5 & Sohobion 5000 Injeksi & 1 & 1,8 \\
6 & Venofer Injeksi & 1 & 1,8 \\
7 & Ikaneuron 5000 Injeksi & 1 & 1,8 \\
8 & Mecobalamin 500 mcg Inj Novell & 15 & 27,3 \\
9 & Citicoline 250 mg Inj Dexa & 1 & 1,8 \\
10 & Medica_Al01 & 1 & 1,8 \\
11 & Dexobion 5000 Injeksi & 4 & 7,3 \\
12 & Natrium Chlorida 100_Al01 $m$ Sanbe & 3 & 5,5 \\
13 & Renxamine Infus & 14 & 25,5 \\
14 & RL Infus Widatra_Al01 & 1 & 1,8 \\
15 & RL Infus Sanbe 500 ml Sp & 2 & 3,6 \\
16 & Nacl 500 ml Infus Sanbe Sp & 2 & 3,6 \\
17 & Epotrex 10000 IU Injeksi & 10 & 18,2 \\
18 & Epotrex 2000 IU Injeksi & 6 & 10,9 \\
19 & Epotrex 4000 IU Injeksi & 2 & 3,6 \\
20 & Hemapo 3000 IU_Al01 & 1 & 1,8 \\
21 & Pulmicort Respules 0.5 mg & 13 & 23,6 \\
22 & Pumpitor 40 mg Injeksi & 1 & 1,8 \\
23 & Ranitidine 50 mg Injeksi & 5 & 9,1 \\
24 & Ondansetron 4 mg Inj Hexpharm-Al01 & 1 & 1,8
\end{tabular}


25 Omeprazole $40 \mathrm{mg}$ Inj Dexa Medica

26

27

28

29

30

31

32

33

34

35

36

37

Pantoprazole $40 \mathrm{mg}$ Inj

Guardian_Al01

Paracetamol Infus 1 G_Al01

Ketorolac Inj $30 \mathrm{mg}$ Phapros

Ketorolac 30 mg Inj Hexpharm

Sagestam $40 \mathrm{mg} / 2 \mathrm{ml}$ Injeksi

Lidocaine Hcl 2 \% Inj Phapros_Al01

Lasix 20 mg Injeksi_Al01

Furosemide Inj 20 mg_A101

Trilac $10 \mathrm{mg} / \mathrm{ml}$ Injeksi

Methylprednisolone Inj $125 \mathrm{mg}$

Ketricin Orabase $0.1 \% 5 \mathrm{gr}$

Piracetam Inj $3 \mathrm{mr}$ Hexpharm

Berdasarkan tabel III, dapat dilihat bahwa pasien rawat inap yang menderita penyakit jantung koroner banyak digunakan jenis obat dengan kelas terapi hormon endokrin dan antidiabetik parenteral yaitu Sansulin Log-G 100 IU/ml Injeksi sebanyak 4 (89,1\%), novorapid flexpen_al01 sebanyak $2(3,6 \%)$ dan sansulin pen sebanyak $1(1,8 \%)$, jenis obat dengan kelas terapi vitamin dan mineral yaitu mecobalamin 500 mcg injeksi nulab sebanyak $9(16,4 \%)$, sohobion 5000 injeksi sebanyak $1(1,8 \%)$, venofer injeksi sebanyak $1(1,8 \%)$, ikaneuron 5000 injeksi sebanyak $1(1,8 \%)$, mecobalamin $500 \mathrm{mcg}$ inj novell sebanyak 15 $(27,3 \%)$, citicoline $250 \mathrm{mg}$ inj dexa medica_al01 sebanyak $1(1,8 \%)$ dan sohobion 5000 injeksi sebanyak $1(1,8 \%)$, jenis obat dengan kelas terapi larutan iv \& steril lainnya yaitu dextrose $40 \%$ injeksi_al01 sebanyak 4 (7,3\%), natrium chlorida $100 \mathrm{ml}$ sanbe sebanyak 3 $(5,5 \%)$, renxamine infus sebanyak $14(25,5 \%)$, rl infus widatra_al01 sebanyak $1(1,8 \%)$, rl infus sanbe $500 \mathrm{ml}$ sp sebanyak 2(3,6\%) dan nacl $500 \mathrm{ml}$ infus sanbe sp sebanyak 2(3,6\%), kemudian jenis obat dengan kelas terapi obat yang mempengaruhi darah yaitu epotrex 10000 iu injeksi sebanyak $10(18,2 \%)$, epotrex 2000 iu injeksi sebanyak 6 (10,9\%), epotrex 4000 iu injeksi sebanyak $2(3,6 \%)$ dan hemapo 3000 iu_al01 sebanyak $1(1,8 \%)$, jenis obat dengan kelas terapi obat untuk saluran nafas yaitu pulmicort respules $0.5 \mathrm{mg}$ sebanyak $13(23,6 \%)$, jenis obat dengan kelas terapi obat untuk saluran cerna yaitu pumpitor $40 \mathrm{mg}$ injeksi sebanyak $1(1,8 \%)$, ranitidine $50 \mathrm{mg}$ injeksi sebanyak $5(9,1 \%)$, ondansetron $4 \mathrm{mg}$ inj hexpharm-al01 sebanyak $1(1,8 \%)$, omeprazole $40 \mathrm{mg}$ inj dexa medica sebanyak $1(1,8 \%)$ dan pantoprazole $40 \mathrm{mg}$ inj guardian_al01 sebanyak $1(1,8 \%)$, jenis obat dengan kelas terapi analgesik non narkotik, antipiretik, antiinflamasi yaitu paracetamol infus 1 g_al01 sebanyak $1(1,8 \%)$, ketorolac inj $30 \mathrm{mg}$ phapros sebanyak $2(3,6 \%)$ dan ketorolac $30 \mathrm{mg}$ inj hexpharm sebanyak $3(5,5 \%)$, jenis obat dengan kelas terapi antibiotik yaitu sagestam $40 \mathrm{mg} / 2 \mathrm{ml}$ injeksi sebanyak $6(10,9 \%)$, jenis obat dengan kelas terapi anestetik lokal yaitu lidocaine hcl $2 \%$ inj phapros_al01 sebanyak $3(5,5 \%)$, jenis obat dengan kelas terapidiuretik yaitulasix 20 mg injeksi_al01 sebanyak $2(3,6 \%)$ dan furosemide inj $20 \mathrm{mg}$ al01 sebanyak $1(1,8 \%)$, jenis obat dengan kelas terapikortikosteroid \& kortikotropin yaitu trilac $10 \mathrm{mg} / \mathrm{ml}$ injeksi sebanyak $1(1,8 \%)$ dan methylprednisolone inj 125 mg sebanyak $2(3,6 \%)$, jenis obat dengan kelas terapiantiinflamasi \& antipiretik yaitu ketricin orabase $0.1 \% 5 \mathrm{gr}$ sebanyak $1(1,8 \%)$ dan jenis obat dengan kelas terapiobat kardiovaskuler yaitu piracetam inj $3 \mathrm{mr}$ hexpharm sebanyak $1(1,8 \%)$.

Berdasarkan penelitian Depkes RI tahun 2006 Penggunaan obat bukan hipertensi yang paling banyak digunakan adalah golongan antidiabetik sebanyak $65,41 \%$ kemudian golongan analgesik sebanyak $8,07 \%$ dan golongan multivitamin sebanyak 5,61\%. [13].

\subsubsection{Profil Penggunaan Obat Oral}

Profil penggunaan obat oral, pasien rawat jalan yang menderita PJK dapat dilihat pada tabel dibawah ini. 
Tabel IV. Presentase Distribusi Jumlah Pasien Berdasarkan Profil Penggunaan obat Oral

\begin{tabular}{|c|c|c|c|}
\hline No & Golongan Obat Berdasarkan Kelas Terapi & Frekuensi & Persentase \% \\
\hline 1 & Kardiovaskular (aspirin, amlodipin, bisoprolol) & 55 & 100 \\
\hline 2 & $\begin{array}{l}\text { Analgesik, antipiretik, antirematik, antipirai } \\
\text { (paracetamol) }\end{array}$ & 49 & 89,1 \\
\hline 3 & Hormon, Endokrin Dan Antidiabetik Oral (glimepirid) & 45 & 81,8 \\
\hline 4 & Obat Untuk Saluran nafas (ambroxol, fenilefrin) & 38 & 69,1 \\
\hline 5 & $\begin{array}{l}\text { Obat Untuk Saluran Cerna (ranitidin, antasida, } \\
\text { lansoprazol) }\end{array}$ & 36 & 65,5 \\
\hline 6 & Obat yang mempengaruhi darah (warfarin) & 31 & 56,4 \\
\hline 7 & Vitamin Dan Mineral (vitamin B, vitamin C) & 27 & 49,1 \\
\hline 8 & Psikofarmaka (amitriptilin, benzodiazepin) & 18 & 32,7 \\
\hline 9 & Kortikosteroid \& Kortikotropin (metilprednisolon) & 14 & 25,5 \\
\hline 10 & Obat yang mempengaruhi saluran kemih & 14 & 25,5 \\
\hline 11 & Antimikroba (amoxicillin) & 9 & 16,4 \\
\hline 12 & $\begin{array}{l}\text { Relaksan otot perifer dan penghambat kolinesterase } \\
\text { (eperison) }\end{array}$ & 6 & 10,9 \\
\hline 13 & Antiparkinson (levodopa) & 3 & 5,5 \\
\hline 14 & Antimigrain (flunarizin) & 1 & 1,8 \\
\hline
\end{tabular}

Berdasarkan tabel IV, golongan obat dengan kelas terapi kardiovaskular sebanyak 55 (100\%) merupakan obat yang paling banyak digunakan oleh pasien rawat jalan dengan jenisnya yaitu aspirin, amlodipin, bisoprolol, simvastatin dan irbesartan, golongan obat dengan kelas terapi analgesik (seperti asam mefenamat), antipiretik (seperti paracetamol), antirematik (seperti dexametason), antipirai (seperti allopurinol) sebanyak $49(89,1 \%)$, hormon, endokrin dan antidiabetik oral sebanyak $45(81,8 \%)$ dengan jenisnya yaitu glimepirid dan metformin, obat untuk saluran nafas sebanyak $38(69,1 \%)$ dengan jenisnya yaitu ambroxol, acetylsistein, difenhidramin dan phenylephrine, golongan obat untuk saluran pencernaan sebanyak $36(65,5 \%)$ dengan jenisnya yaitu ranitidin, loratadin, lansoprazole dan antasida, golongan obat yang mempengaruhi darah sebanyak $31(56,4 \%)$ seperti warfarin, golongan obat dengan kelas terapivitamin dan mineral sebanyak $27(49,1 \%)$ dengan jenisnya yaitu mecobalamin, vitamin B kompleks dan vitamin C, golongan obat dengan kelas terapi psikofarmaka sebanyak $18(32,7 \%)$ seperti amitriptilin dan benzodiazepin, golongan obat dengan kelas terapikortikosteroid \& kortikotropin $14(25,5 \%)$ dengan jenisnya yaitu deksametason, metilprednisolon, prednison dan triamsinolon, golongan obat dengan kelas terapi saluran kemih sebanyak $14(25,5 \%)$, golongan obat dengan kelas terapi antimikroba sebanyak $9(16,4 \%)$ seperti amoxicillin dan ciprofloxacin, golongan obat dengan kelas terapi relaksan otot perifer dan kolinesterase inhibitor sebanyak $6(10,9 \%)$ seperti eperison,golongan obat dengan kelas terapi antiparkinson sebanyak $3(5,5 \%)$ seperti levodopa, dan golongan obat dengan kelas terapi antimigrain sebanyak $1(1,8 \%)$ seperti flunarizin.

\subsubsection{Profil Penggunaan Obat Kardiovaskular}

Tabel V. Profil Penggunaan Obat Kardiovaskular pada Penyakit Jantung Koroner dengan Penyerta

\begin{tabular}{llcc}
\hline No & \multicolumn{1}{c}{ Nama Obat } & Frekuensi & Persentase $(\%)$ \\
\hline 1. & Isosorbide dinitrate & 28 & 50,9 \\
2. & Isosorbide mononitrate & 2 & 3,6 \\
3. & Amiodarone & 3 & 5,5 \\
4. & Ramipril & 16 & 29,1 \\
5. & Captopril & 2 & 3,6
\end{tabular}




\begin{tabular}{llcc} 
6. & Amlodipine & 50 & 90,9 \\
7. & Nifedipin & 6 & 10,9 \\
8. & Diltiazem & 10 & 18,2 \\
9. & Carvedilol & 13 & 23,6 \\
10. & Bisoprolol & 47 & 85,5 \\
11. & Losartan & 3 & 5,5 \\
12. & Irbesartan & 21 & 38,2 \\
13. & Candesartan & 16 & 29,1 \\
14. & Simvastatin & 53 & 96,4 \\
15. & Atorvastatin & 44 & 80 \\
16. & Citicoline & 4 & 7,3 \\
17. & Piracetam & 1 & 1,8 \\
18. & Spironolactone & 4 & 7,3 \\
19. & Furosemide & 13 & 23,6 \\
20. & Clopidogrel & 41 & 74,5 \\
21. & Aspirin & 51 & 92,7 \\
22. & Cilostazol & 8 & 14,5 \\
23. & Beraprost Na & 6 & 10,9 \\
\hline
\end{tabular}

Berdasarkan tabel $\mathrm{V}$, penggunaan obat antiplatelet merupakan yang paling banyak digunakan oleh pasien rawat jalan penderita penyakit jantung koroner dengan jenisnya yaitu aspirin sebanyak $51(92,7 \%)$ dan clopidogrel sebanyak $41(74,5 \%)$, golongan obat statin yaitu simvastatin sebanyak $53(96,4 \%)$ dan atorvastatin sebesar $44(80 \%)$, golongan obat CCB yaitu amlodipine sebanyak 50 (90,9\%), diltiazem sebanyak $10(18,2 \%)$ dan nifedipin sebanyak $6(10,9 \%)$, golongan obat penyekat beta yaitu bisoprolol sebanyak $47(85,5 \%)$ dan carvedilol sebanyak $13(23,6 \%)$, golongan obat penghambat reseptor angiotensin yaitu irbesartan sebanyak $21(38,2 \%)$, candesartan sebanyak $16(29,1 \%)$ dan losartan sebanyak 3 $(5,5 \%)$, golongan obat nitrat yaitu isosorbide dinitrate sebanyak $28(50,9 \%)$ dan isosorbide mononitrate sebanyak 2 (3,6\%), golongan obat diuretik yaitu furosemide sebanyak 13 $(23,6 \%)$ dan spironolactone sebanyak $4(7,3 \%)$, obat cilostazol sebanyak $8(14,5 \%)$, beraprost $\mathrm{Na}$ sebanyak 6 (10,9\%), obat citicoline sebanyak 4 (7,3\%), obat amiodarone sebanyak $3(5,5 \%)$ dan obat piracetam sebanyak $1(1,8 \%)$.

Menurut Dipiro dkk (2008), obat amplodipine sebesar 28,79\% merupakan obat antihipertensi golongan CCB yang dapat digunakan untuk mengendalikan tekanan darah pada pasien hipertensi dengan komplikasi diabetes mellitus [12].

\subsubsection{Jumlah Pengggunaan Obat}

Berdasarkan profil penggunaan obat yang digunakan oleh pasien dengan diagnosa penyakit jantung koroner pada bulan Januari - Desember 2019 di dapatkan bahwa penggunaan obat selama dirawat jalan pada sediaan injeksi (Tabel III) dan sediaan oral (Tabel IV). Dan berdasarkan pengelompokan jenis penggunaan obat yang digunakan masing-masing pasien dapat digambarkan pada tabel di bawah ini.

\begin{tabular}{|c|c|c|}
\hline $\begin{array}{l}\text { Jumlah jenis Penggunaan Obat Pasien } \\
\text { (Annisa, 2016) }\end{array}$ & Jumlah Pasien & $\begin{array}{c}\text { Persentase } \\
\%\end{array}$ \\
\hline $1-5$ obat & 9 & 16,4 \\
\hline 6-10 obat & 24 & 43,6 \\
\hline$>10$ obat & 22 & 40 \\
\hline Total & 55 & 100 \\
\hline
\end{tabular}

Berdasarkan tabel VI, jenis penggunaan obat 6 - 10 merupakan obat yang paling banyak diterima pasien yaitu sebanyak 24 pasien $(43,6 \%)$ dari total pasien 55 pasien, diikuti jenis obat $>10$ sebanyak 22 pasien (40\%). Sedangkan untuk pasien yang menggunakan 1-5 jenis obat sebanyak 9 pasien $(16,4 \%)$. 
Pada penelitian terkait jumlah obat menunjukkan hasil yang hampir sama dengan penelitian yang dilakukan oleh Wono (2005), dimana jumlah obat yang diterima oleh tiap pasien PJK paling banyak adalah $\geq 5$ jenis obat selama dirawat, hal ini dikarenakan pasien PJK juga mengalami penyakit penyerta yang membutuhkan berbagai macam obat dalam terapinya [14].

\subsection{Profil Biaya}

Total biaya jenis obat kardiovaskular

Pemilihan jenis obat kardiovaskuar untuk menentukan pengobatan seorang pasien ada beberapa yaitu riwayat penyakit, faktor risiko, kebiasaan olahraga, tindakan dan prosedur diagnostik yang telah dilakukan, gejala yang dialami, pemeriksaan fisik, pemeriksaan laboratorium glukosa darah, pengobatan dan tindakan, indikasi dan kontra indikasi dan startifikasi resiko.

Tabel VII. Total Harga Penggunaan Jenis Obat Kardiovaskular Yang Digunakan Semua Pasien Rawat Jalan Penyakit Jantung Koroner Dengan Penyakit Penyerta Di Rumah Sakit X Kabupaten Cilacap

\begin{tabular}{|c|c|c|c|c|}
\hline No & Nama Obat & $\begin{array}{c}\text { Jumla } \\
\mathrm{h}\end{array}$ & $\begin{array}{l}\text { Harga } \\
\text { Satuan } \\
(\mathrm{Rp})\end{array}$ & $\begin{array}{c}\text { Total } \\
\text { Harga } \\
(\mathrm{Rp})\end{array}$ \\
\hline 1 & Nifedipin $10 \mathrm{mg}$ tablet & 63 & 320 & 20.160 \\
\hline 2 & Cordila SR $180 \mathrm{mg}$ tablet & 75 & 7.208 & 540.600 \\
\hline 3 & Dilmen $60 \mathrm{mg}$ tablet & 330 & 996 & 328.680 \\
\hline 4 & Diltiazem $30 \mathrm{mg}$ tab dexa medica & 120 & 193 & 23.160 \\
\hline 5 & Isosorbide dinitrate tab $10 \mathrm{mg}$ & 147 & 427 & 62.769 \\
\hline 6 & Isosorbide dinitrate $5 \mathrm{mg}$ tab yarindo & 1.036 & 257 & 266.252 \\
\hline 7 & Cedocard $5 \mathrm{mg}$ tablet & 60 & 1.763 & 105.780 \\
\hline 8 & Cardismo $20 \mathrm{mg}$ tablet & 45 & 2.676 & 120.420 \\
\hline 9 & Kendaron $200 \mathrm{mg}$ tab & 105 & 1.448 & 152.040 \\
\hline 10 & Ramipril tab 2,5 mg & 30 & 447 & 13.410 \\
\hline 11 & Ramipril 5 mg & 60 & 811 & 48.811 \\
\hline 12 & Ramipril $5 \mathrm{mg}$ tab dexa medica & 331 & 946 & 313.126 \\
\hline 13 & Ramipril tab $10 \mathrm{mg}$ & 15 & 1.434 & 21.510 \\
\hline 14 & Captopril $12,5 \mathrm{mg}$ tab dexa medica & 180 & 127 & 22.870 \\
\hline 15 & Captopril tab $25 \mathrm{mg}$ & 1 & 224 & 224 \\
\hline 16 & Amlodipine tab $5 \mathrm{mg} \mathrm{kf}$ & 90 & 179 & 16.110 \\
\hline 17 & Amlodipine tab $5 \mathrm{mg}$ & 270 & 262 & 70.262 \\
\hline 18 & Dilavask tab $5 \mathrm{mg}$ & 120 & 758 & 90.960 \\
\hline 19 & $\begin{array}{l}\text { Amlodipine besylate } 5 \mathrm{mg} \text { tab kimia } \\
\text { farma }\end{array}$ & 783 & 1.692 & 1.324 .836 \\
\hline 20 & Amlodipine $5 \mathrm{mg}$ tab hexpharm & 390 & 236 & 92.040 \\
\hline 21 & Vibloc $25 \mathrm{mg}$ tablet & 8 & 5.952 & 47.952 \\
\hline 22 & Vibloc $6,25 \mathrm{mg}$ tablet & 300 & 3.497 & 1.049 .100 \\
\hline 23 & Bisoprolol $5 \mathrm{mg}$ tab novell & 365 & 1.872 & 683.280 \\
\hline 24 & Santesar $50 \mathrm{mg}$ tablet & 60 & 7.343 & 440.580 \\
\hline 25 & Irtan $150 \mathrm{mg}$ tablet & 120 & 6.045 & 725.400 \\
\hline 26 & Irbesartan $150 \mathrm{mg}$ tab landson & 60 & 1.409 & 84.540 \\
\hline 27 & Irbesartan $150 \mathrm{mg}$ tab indo farma & 120 & 6.975 & 837.000 \\
\hline 28 & Irtan $300 \mathrm{mg}$ tablet & 105 & 9.068 & 952.140 \\
\hline 29 & Irbesartan $300 \mathrm{mg}$ tablet indo farma & 15 & 5.909 & 88,635 \\
\hline 30 & Candesartan $8 \mathrm{mg}$ tab dexa medica & 220 & 7.926 & 1.743 .720 \\
\hline 31 & Candesartan $8 \mathrm{mg}$ tab novell & 15 & 2.163 & 32.445 \\
\hline 32 & Candesartan $16 \mathrm{mg}$ tab novell & 90 & 11.743 & 1.056 .870 \\
\hline
\end{tabular}




$\begin{array}{llcrr}33 & \text { Simvastatin tab 10 mg } & 1.473 & 836 & 1.231 .428 \\ 34 & \text { Esvat 20 mg tablet } & 120 & 1.453 & 174.360 \\ 35 & \text { Simvastatin tab 20 mg } & 443 & 631 & 279.533 \\ 36 & \text { Cholestor 10 mg tablet } & 360 & 3.953 & 1.423 .080\end{array}$

\begin{tabular}{llcrr}
\hline 37 & Atorvastatin 20 mg tablet fahrenheit & 331 & 7.146 & 2.365 .326 \\
\hline 38 & Atorvastatin 20 mg tablet & 510 & 5.249 & 2.676 .990 \\
\hline 39 & Atorvastatin tab 20 mg novell & 75 & 2.790 & 209.250 \\
\hline 40 & Atorvastatin 40 mg tab fahrenheit & 15 & 5.038 & 75.570 \\
\hline 41 & Atorvastatin 40 mg tab & 129 & 6.024 & 777.096 \\
\hline 42 & Citicoline 500 mg tab hexpharm & 50 & 5.115 & 255.750 \\
\hline 43 & Citicoline 250 mg inj dexa medica & 1 & 28.133 & 28.133 \\
\hline 44 & Piracetam inj 3 gr hexpharm & 1 & 10.912 & 10.912 \\
45 & Spironolactone 25 mg tab dexa medica & 120 & 424 & 50.880 \\
46 & Furosemide tab 40 mg fahrenheit & 80 & 310 & 24.800 \\
47 & Furosemide 40 mg tab kimia farma & 108 & 198 & 21.384 \\
48 & Lasix 20 mg injeksi & 2 & 27.827 & 55.654 \\
49 & Furosemide inj 20 mg & 1 & 30.471 & 30.471 \\
50 & Clopidogrel 75 mg tab kimia farma & 765 & 3.111 & 2.379 .915 \\
51 & Clopidogrel 75 mg tab kimia farma_al01 & 384 & 16.113 & 6.187 .392 \\
52 & Naletal 100 mg tablet & 248 & 6.348 & 1.574 .304 \\
53 & Dorner 20 mcg tablet & 150 & 10.309 & 1.546 .350 \\
54 & Thrombo aspilets 80 mg tablet & 90 & 1.209 & 108.810 \\
55 & Miniaspi tab 80 mg & 10 & 665 & 6.650 \\
56 & Cartylo tab 80 mg & 100 & 955 & 95.500 \\
57 & Astika 100 mg tablet & 1.950 & 512 & 998.400 \\
58 & Aspilets chewable 80 mg & 30 & 904 & 27.120 \\
\hline & TOTAL & & & 35.367 .890 \\
\hline & & &
\end{tabular}

Berdasarkan tabel VII, total biaya terapi penggunaan obat kardiovaskular pada seluruh pasien dengan penyakit jantung koroner dengan penyakit penyerta selama menjalani rawat jalan di Rumah Sakit X Kabupaten Cilacap pada periode Januari - Desember 2019 adalah sebesar Rp 35.367.890. Hal ini dapat disimpulkan bahwa penyakit jantung koroner dengan penyakit penyerta membutuhkan biaya terapi penggunaan obat kardiovaskular yang lebih banyak dibandingkan dengan penyakit jantung koroner tanpa penyakit penyerta dan adanya penyakit penyerta dapat mempengaruhi total biaya terapi penggunaan obat kardiovaskular, karena semakin banyak penyakit penyerta yang diderita oleh pasien penyakit jantung koroner tentu akan membutuhkan biaya terapi yang banyak.

3.4 Uji Analisis

\subsubsection{Uji Normalitas}

Data mentah yang didapatkan akan dilakukan pengujian normalitas untuk mengetahui sampel tersebut terdistribusi normal atau tidak. Pengujian normalitas data menggunakan Kolmogorov smirnov test tertera pada tabel berikut :

Tabel VIII. Hasil uji normalitas One-Sample Kolmogorov-Smirnov Test

\begin{tabular}{|c|c|c|}
\hline & & Unstandardized Residual \\
\hline $\mathrm{N}$ & & 55 \\
\hline \multirow[t]{2}{*}{ Normal Parameters ${ }^{a . b}$} & Mean & .0000000 \\
\hline & Std. Deviation & $3.54700930 \mathrm{E} 5$ \\
\hline Most Extreme Differences & Absolute & .062 \\
\hline
\end{tabular}




\begin{tabular}{llr}
\hline & Positive & .062 \\
& Negative & $* .061$ \\
Kolmogorov-Smirnov Z & & .461 \\
Asymp. Sig. (2-tailed) & & .984 \\
\hline (sumber : Hasil Analisis SPSS) &
\end{tabular}

Berdasarkan tabel VIII, dapat dilihat bahwa nilai Asymp. Sig. (2-tailed) sebesar 0,984 (> 0.05), maka $\mathrm{H} 0$ diterima atau data residual terdistribusi normal. H0 diterima karena antara penggunaan obat kardiovaskular dengan biaya terapi pengobatan penyakit jantung koroner terdistribusi normal (variabel hasilnya sesuai kriteria normal pada uji analisis SPSS). Data yang diperoleh normal, selanjutnya dilanjutkan uji statistik pearson untuk melihat korelasi antara penggunaan obat kardiovaskular dengan biaya terapi pengobatan penyakit jantung koroner pada pasien penyakit jantung koroner dengan penyakit penyerta yang menjalani rawat jalan di Rumah Sakit X Kabupaten Cilacap periode Januari - Desember 2019.

\subsubsection{Uji Pearson}

Data penggunaan obat kardiovaskular dan biaya terapi pengobatan penyakit jantung koroner telah diuji normalitasnya dan menghasilkan Sig yang normal sehingga perlu dilakukan uji statistika dengan menggunakan uji statistika pearson.

Tabel IX. Hasil uji Correlations antara Penggunaan obat kardiovaskular dan biaya terapi pengobatan penyakit jantung koroner

\begin{tabular}{|c|c|c|c|}
\hline & & $\begin{array}{c}\text { Jumlah obat } \\
\text { kardiovaskular }\end{array}$ & $\begin{array}{c}\text { Jumlah biaya } \\
\text { obat } \\
\text { kardiovaskular }\end{array}$ \\
\hline \multirow{3}{*}{$\begin{array}{l}\text { Jumlah obat } \\
\text { kardiovaskular }\end{array}$} & $\begin{array}{l}\text { Pearson } \\
\text { Correlation }\end{array}$ & 1 & $.746^{* *}$ \\
\hline & Sig. (2-tailed) & & .000 \\
\hline & $\mathrm{N}$ & 55 & 55 \\
\hline \multirow{3}{*}{$\begin{array}{l}\text { Jumlah biaya obat } \\
\text { kardiovaskular }\end{array}$} & $\begin{array}{l}\text { Pearson } \\
\text { Correlation }\end{array}$ & $.746 * *$ & 1 \\
\hline & Sig. (2-tailed) & .000 & \\
\hline & $\mathrm{N}$ & 55 & 55 \\
\hline
\end{tabular}

(sumber : Hasil Analisis SPSS)

Berdasarkan tabel IX, diperoleh nilai koefisien korelasi sebesar 0,746 dengan nilai signifikansi / $\mathrm{p}$ value sebesar 0,000, karena nilai signifikansi $\mathrm{p}<0,05$, maka Ha diterima, artinya ada hubungan signifikan positif antara penggunaan obat kardiovaskular dan biaya terapi pengobatan penyakit jantung koroner. Tanda pada harga koefisien korelasi juga berpengaruh pada penafsiran terhadap hasil analisis korelasi, yaitu positif $(+)$ menunjukkan adanya arah hubungan yang searah, artinya hubungan kedua variabel berbanding lurus.

Jadi semakin banyak jumlah obat yang digunakan pasien maka akan semakin banyak biaya yang akan dikeluarkan oleh pasien tersebut dalam melakukan pengobatan penyakit jantung koroner dengan penyakit penyerta pengobatan selama rawat jalan khususnya di Rumah Sakit X Kabupaten Cilacap.

\subsubsection{Koefisien determinasi}

Koefisien determinasi pada regresi linear dapat diartikan sebagai seberapa besar kemampuan semua variabel bebas dalam menjelaskan varians dari variabel terikatnya. Secara sederhana koefisien determinasi dihitung dengan mengkuadratkan Koefisien Korelasi (R). Dalam penelitian ini besarnya nilai koefisien determinasi adalah sebesar $=0,746 \times 0,746$ $=0,556$. Berarti kemampuan variabel bebas dalam menjelaskan varians dari variabel terikatnya adalah sebesar 55,6\%. Berarti terdapat $44,4 \%(100 \%-55,6 \%)$ varians variabel terikat yang dijelaskan oleh faktor lain. 
Berdasarkan tabel IX, terlihat koefisien korelasi Pearson product moment jumlah biaya obat kardiovaskular sebesar $.746^{* *}$. Artinya besar korelasi atau hubungan antara variabel Jumlah obat kardiovaskular dan Jumlah biaya obat kardiovaskular ialah sebesar 0,746 atau sangat kuat karena mendekati angka 1 .

Hubungan signifikan tersebut dibuktikan oleh pasien penyakit jantung koroner dengan penyerta yang lebih banyak dan melakukan pengobatan rutin selama 1 tahun memiliki biaya pengobatan yang lebih banyak pula. Sedangkan pasien penyakit jantung koroner dengan 1 penyerta dan melakukan pengobatan secara berkala selama 1 tahun memiliki biaya pengobatan yang lebih sedikit pula.

\section{KESIMPULAN}

Profil penggunaan terapi obat kardiovaskular pada pasien penyakit jantung koroner dengan penyakit penyerta di rawat jalan Rumah Sakit X Kabupaten Cilacap selama periode Januari - Desember 2019 yang paling banyak digunakan adalah golongan obat adalah golongan obat antiplatelet yaitu aspirin sebanyak 51 (92,7\%) dan clopidogrel sebanyak 41 (74,5\%). Sedangkan penggunaan obat kardiovaskular yang paling sedikit digunakan adalah obat piracetam sebanyak $1(1,8 \%)$. Profil biaya terapi penggunaan obat kardiovaskular yang paling banyak digunakan yaitu obat clopidogrel dengan jumlah pengeluaran sebesar Rp 8.567.307. Sedangkan penggunaan obat kardiovaskular yang paling sedikit digunakan yaitu obat captopril dengan jumlah sebesar Rp 224. Penggunaan jumlah obat kardiovaskular dengan biaya terapi penggunaan obat kardiovaskular memiliki hubungan dengan tingkat hubungan korelasi yang kuat. Sehingga penggunaan jumlah obat kardiovaskular yang banyak tentu membutuhkan biaya terapi penggunaan obat kardiovaskular yang banyak.

\section{DAFTAR PUSTAKA}

[1] Kemenkes RI. 2017. Penyakit Jantung Penyebab Kematian Tertinggi. Kementrian Kesehatan Republik Indonesia. Pp. 2015-2016. Available At: Https://Www.Depkes.Go.Id/Article/View/17073100005/Penyakit-Jantung-PenyebabKematian-Tertinggi-Kemenkes-Ingatkan-Cerdik.Html. [Accessed January 2020].

[2] Ghani LK Mihardja dan Delima. 2015. Faktor Resiko Dominan Penderita Stroke di Indonesia. Jakarta : Buletin Penelitian Kesehatan Badan Litbangkes Kemenkes RI. Vol. 44, No 1.

[3] Survei Sample Registration System (SRS). 2014. Penyakit Jantung Koroner (Pjk). Jakarta : Kemenkes RI.

[4] BPS (2016) 'Statistik Indonesia Statistical Yearbook Of Indonesia 2016', p. 720.

[5] Soewondo, P. (2014) 'Harapan Baru Penyandang Diabetes Mellitus pada Era Jaminan Kesehatan Nasional 2014', 2(1), pp. 1-6.

[6] American Heart Association (AHA). 2016. Heart Disease and Stroke Statistics at Aglance. AvailableAt:https://www.heart.org/idc/groups/ahamahpublic/@wcm/@ sop/@smd/docume nts/downloadable/ucm 470704.pdf. [Accessed January 2020].

[7] Anna Aurelia, Eka Pujiyanti (2015) Biaya Satuan dan Pemulihan Biaya (Cost Recovery Rate) Layanan Pasien Acute Coronary Syndrome dengan Rawat Inap Di Rumah Sakit X Tahun 2015. Jurnal Ekonomi Kesehatan Indonesia.Universitas Indonesia. Depok. PP. 132137.

[8] Sari, L. S. 2014. Analisis Biaya Akibat Sakit Serta Kualitas Hidup Pasien Diabetes Mellitus Tipe 2 Dengan Penyakit Jantung. Jurnal Ekonomi Kesehatan Indonesia.Universitas Indonesia. Depok. Vol. 1. No. 3. Pp 126-131.

[9] Martha, A. F. (2016) Evaluasi Drug Related Problems (Drps) Pada Pasien Dengan Diagnosa Jantung Koroner Di Salah Satu Rumah Sakit Jakarta Utara. Skripsi. UIN Syarif Hidayatullah. Jakarta. 
[10] Wahyuni, S. H. (2014) 'Usia, Jenis Kelamin Dan Riwayat Keluarga Penyakit Jantung Koroner Sebagai Faktor Prediktor Terjadinya Major Adverse Cardiac Events Pada Pasien Sindrom Koroner Akut', P. 54.

[11] Nahandi, C. I. (2018) 'Analisis Biaya Obat Paisen Diabetes Melitus Tipe Ii Rawat Inap Rsud Dr. Haryoto Kabupaten Lumajang Periode Januari 2017-Agustus 2018', SKRIPSI, 2, pp. 6-11; 74.

[12] Fatmawati, F. Et Al. (2018) 'Analisis Biaya Terapi Pasien Hipertensi Dengan Komplikasi Diabetes Mellitus Rawat Jalan Di Rsi Pku Muhammadiyah Pekajangan Tahun 2014 2017. Analysis Of Cost Hypertensive Patients With Diabetes Mellitus Complications At Rsi Pku Muhammadiyah The 8 Th Uni', Pp. 463-469.

[13] Rismi Fatoni, Abdul Gofir, S. (2014) 'Klopidogrel Dengan Aspirin Tunggal Pada Stroke Iskemik Comparison Of The Benefit Of Antiplatelet Of Aspirin-Clopidogrel', Pp. 257263.

[14] Gabriella N.Taroreh et.al (2017) 'Evaluasi Penggunaan Obat Pada Pasien Dengan Penyakit Jantung Koroner Di Instalasi Rawat Inap Rsup Prof. Dr. R. D. Kandou Manado', Pharmacon, 6(4), pp. 55-66. 